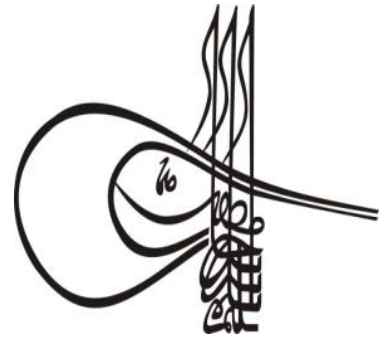

Received/Geliş: 24.02.2019

Gor Report Dates/Rapor Tarihleri: Referee 1 (14.03.2019)-Referee 2 (25.03.2019)
Turkigh Studies

\section{Language and Literature}

Volume 14 Issue 2, 2019, p. 891-903

DOI: 10.29228/TurkishStudies.22769

ISSN: 2667-5641

Skopje/MACEDONIA-Ankara/TURKEY

Research Article / Araştırma Makalesi

Article Info/Makale Bilgisi

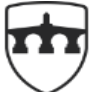

INTERNATIONAL BALKAN UNIVERSITY

EXCELLENCE FOR THE FUTURE IBU.EDU.MK

This article was checked by iThenticate.

\title{
17. YÜZYILA AİT ÇOK DİLLİ BİR SÖZLÜK: TERCEME-İ LÛGAT-I HINNDî
}

\author{
Ali Kemal ŞAŞ*
}

SAccepted/Kabul: 10.06 .2019

\begin{abstract}
öz
Kaşgarlı Mahmut'un büyük eseri Divan-1 Lûgâti't-Türk'le başlayan Türk sözlükçülüğü zaman içerisinde önemli bir aşama kaydetmiştir. Oldukça geniş bir coğrafyada konuşulan Türkçenin, yöntem ve içerik itibarıyla birbirinden oldukça farklı sözlükleri vücuda getirilmiştir. Türkçe temelli, yani Türkçe kelimeler madde başı yapılarak oluşturulan sözlükler 18. yüzyılın ortalarından itibaren görülmeye başlamıștır. Bu tarihten önce Osmanlı sahasında hazırlanmıs sözlükler yabancı bir dili öğretmek maksadıyla yazılmış iki veya çok dilli sözlüklerdir. Bu sözlükler başlangıçta Arapça - Türkçe, Farsça - Türkçe veya Arapça - Farsça Türkçe şeklinde tertip edilmiştir. Zamanla gelişen ve çok kültürlü bir yapıya sahip olan Osmanlı toplumunda, Arapça ve Farsça söz varlığını içeren sözlüklerin yanında, birlikte yaşanan veya kültürel, siyasi ve iktisadi münasebetler kurulan milletlerin dillerini içeren sözlükler de hazırlanmıştır. Bu sözlüklerden biri de 17 . yüzyılın ikinci yarısında Hintçe - Farsça - Türkçe şeklinde tertip edilmiş olan Terceme-i Lûgat-1 Hindî'dir.

Osmanlı Dönemi'ne ait tek Hintçe - Farsça - Türkçe sözlük olma özelliğini taşıyan Terceme-i Lûgat-1 Hindî, 17. yüzyılın önemli âlimlerinden Hezarfen Hüseyin Efendi tarafından kaleme alınmıştır. 1678'de yazılmaya başlanan eserin müellif hattı bugün için meçhuldür. Eserin bilinen tek nüshası 1806'da istinsah edilmiştir. Arap alfabesindeki sıra esas alınarak hece sisteminde dizilmiş olan eserde toplam 623 Hintçe madde başı kelime ve kelime öbeğinin Farsça ve Türkçe karşılıkları verilmiştir. Bu çalışmada Terceme-i Lûgat-1 Hindînnin sözlük bilimsel özellikleri belirlenmeye çalışılmıştır.
\end{abstract}


Anahtar Kelimeler: Sözlük Bilimi, Terceme-i Lûgat-1 Hindî, HintçeTürkçe Sözlük, Hezarfen Hüseyin Efendi

\title{
A MULTILINGUAL DICTIONARY FROM THE 17th CENTURY: TERCEME-I LÛGAT-I HINDÎ
}

\begin{abstract}
Turk lexicology started with Diwanu Lugati't-Turk, the great work of Mahmud Kashgari, and made significant progress over time. Many dictionaries were prepared in Turkish, which was spoken in a wide area. Turkish dictionaries began to be seen from the middle of the 18th century. Dictionaries before this date are bilingual and multilingual dictionaries prepared to teach a foreign language. These dictionaries were originally written in Arabic - Turkish, Persian - Turkish or Arabic Persian - Turkish. In the course of time, the Ottoman society formed a developed and multicultural structure. For this reason, in addition to the dictionaries containing Arabic and Persian vocabulary, dictionaries containing the languages of the nations that have been living together or which have been established cultural, political and economic relations have been prepared. One of these dictionaries is Terceme-i Lûgat-1 Hindî, which was organized in the form of Hindi - Persian - Turkish in the second half of the 17 th century.

Terceme-i Lûgat-1 Hindi, the only Hindi - Persian - Turkish dictionary written in the Ottoman period, was written by Hezarfen Hüseyin Efendi, a prominent scholar of the 17th century. The original of the work which was started to be written in 1678 is unknown. The only known copy of the work was obtained in 1806. In the work which is prepared according to the tradition of Arabic lexicography, a total of 623 Hindi headword and Persian and Turkish equivalents are given. In this study, the lexicographic features of Terceme-i Lûgat-1 Hindî have been tried to be determined.
\end{abstract}

\section{STRUCTURED ABSTRACT}

Turk lexicology started with Diwanu Lûgati't-Turk, the great work of Mahmud Kashgari, and made significant progress over time. Many different dictionaries of Turkish, which are spoken in a wide geography, are written in terms of method and content. Dictionaries such as Mukaddimetü'l-Edeb, Hilyetü'l-İnsân ve Habbetü'1-Lisan, Codex Comanicus, Bahşayiş Lûgati, Kitâb-1 Mecmu-1 Tercüman-1 Türkî ve Acemî ve Mugalî, Kitâbü'l-İdrâk li-Lisâni'l-Etrâk, Kirâbü'l-Ef'al, Kitâbü'tTuhfeti'z-Zekiyye fil-Lûgati't-Türkiyye, Kitâbü Bulgatü'l-Müştâk fî Lûgati't-Türk ve'1-Kıfçak, Ed-Durretü'l-Mudiyye fi'l-Lûgati't-Türkiyye, EşŞüzurü'z-Zehebiyye ve'l-Kitau'l-Ahmediyye fi'l-Lûgati't-Türkiyye, Muhakemetü'l Lûgateyn, Abuşka Lûgati, Bedayiül-Lûgat, Senglah, Hulâsa-i Abbasî, Lûgat-1 Çağatay and Türkî-i Osmânî are written after the Divan-1 Lûgâti't-Türk, are the most important indicators of this development.

One of the purposes of writing dictionaries is to teach a foreign language. The first dictionaries in the Ottoman Empire are bilingual 
dictionaries prepared to teach a foreign language. The first example of such dictionaries is Lûgat-1 Ferișteoğlu, written by Ferișteoğlu in 14th century as Arabic - Turkish. Turkish dictionaries began to be seen from the middle of the 18th century. Dictionaries written before this date are mostly Arabic-Turkish or Persian-Turkish.

Arabic and Persian were adopted by the Ottoman intellectuals and used extensively. Intensive use of these languages in scientific, religious and literary fields has provided the basis for the creation of multilingual dictionaries such as Arabic - Turkish, Persian - Turkish, Arabic - Persian - Turkish, Persian - Arabic - Turkish. In the Ottoman society which has a multicultural structure, in addition to the dictionaries containing Arabic and Persian vocabulary, dictionaries containing the languages of the nations which have been living together or which have cultural, political and economic relations have been prepared. One of these dictionaries is Terceme-i Lûgat-1 Hindî, which was written in HindiPersian-Turkish in the second half of the 17th century.

The Turks have lived in India for a long time and established states here. During this period, multi-lingual dictionaries such as Cevâhirnâme-i Kalem, Garaibü'l-Lûgat, Nisâb-1 Şeş Zebân, Lûgat-1 Türkî ve Fârsî ve Arabî ve Hindî, Lûgat-1 Arabî Fârsî Hindî Türkî ve Agrezî, Nisâb-1 Şeş Lûgat which includes the vocabulary of both Hindi and Turkish were organized. According to the dates in the manuscripts these dictionaries which were started to be written from the Babur ruler Alemgir period were written to meet social, political, religious and commercial needs. In addition to the Turkish and Hindî, languages such as Persian, Arabic, Kashmiri, Urdu and Pashto were also included in these dictionaries. Due to the Spice Route, the presence of intensive commercial activity in the region is the main factor that constitutes these multilingual dictionaries.

Ottoman intellectuals were not interested in Hindi because of the great distance between India and Anatolia and the intensive use of Persian in both geographies. This situation also affected the Ottoman lexicography and only the Terceme-i Lûgat-1 Hindî was written as a HindiTurkish dictionary in the Ottoman Empire.

Terceme-i Lûgat-1 Hindî, was written by Hezarfen Hüseyin Efendi, one of the important scholars of the 17th century. Although he is better known as a historian, he is also an important linguist and lexicographer. In addition to Arabic and Persian, Hezarfen, who also knows languages such as Greek, Hebrew and Latin, is the author of dictionaries like Tuhfetü'l-Erîbin-Nâfi'a lir-Rûhânî ve'-Tabîb, Lisânü'1-Etibbâ fî Lûgati'lEdviye, Fihrisü'1-Ervâm and Terceme-i Lûgat-1 Hindî.

The original copy of Terceme-i Lûgat-1 Hindî, which started to be written on 21 June 1678, is unknown today. The only known copy of the work was written in 1806. The only known copy of this work which has not been studied until now, is in the Rare Books Library of Istanbul University. The book, which is covered with brown leather, consists of 69 pages. The headlines and lexical entries of the work, which are arranged to have 19-23 lines on each page, are written in red ink.

One of the purposes of writing multilingual dictionaries is to facilitate political, commercial and cultural relations between different societies. Terceme-i Lûgat-1 Hindî has been organized in order to be able 
to read literary and scientific works of Ottoman intellectuals who do not speak Hindi. The work, written in the second half of the 17 th century, shows that there is also an interest in Hindi in the Ottoman society and that Indian-Turkish relations have increased in this period. The work will contribute to clarify the historical course of Turkish - Hindi / Urdu relations in the Ottoman period as the only Hindi - Persian - Turkish dictionary.

As a result of our review, we saw lexicological elements in Tercemei Lûgat-1 Hindî, such as phonlogical information, definition information, etymological information, grammar information, usage label and examples. This dictionary, which consists of a total of 69 pages and 623 headword, is a very important work for Turkish lexicography because it has a rich vocabulary and reflects the characteristic features of multilingual historical Turkish dictionaries.

Keywords: Lexicography, Terceme-i Lûgat-1 Hindî, Hindi-Turkish Dictionary, Hezarfen Hüseyin Efendi

\section{Giriş}

Bilinen en eski sözlük, MÖ 2300 civarında Sümerce-Akadca karşılıklar k1lavuzu şeklinde düzenlenmiş Urra Hubullu'dur. Modern sözlüklerden oldukça farklı olan bu eser, yirmi dört tabletten oluşmaktadır. (Akalın, 2010: 268; Kramer, 1990: 4). Bu eserden sonra Çinli Ke Ye Wang'ın MÖ 11. yüzyılda yazdığı Yu Pi En, Hintli Amarasimha'nın MÖ 6. yüzyılda kaleme aldığı Amarakosa, Yunan Protogaros'ın MÖ 5. yüzyılda tertip ettiği Glossai ve Latin Verrius Flaccus'un MÖ 1. yüzyılda düzenlemiş olduğu Libri de signifcatu verborum gibi eserlerle dünyadaki sözlükçülük geleneğinin başladığı söylenebilir (Aksan, 2007: 69; Dilaçar, 1968: 188; Eminoğlu, 2010: 8; Yıldız, 1998: 199).

Türk sözlükçülüğünü de fazlasıyla etkilemiş olan Arap sözlükçülüğü Kuran’1 anlamak ve muhafaza etmek amacıyla yapılan gramer çalışmalarıyla ortaya çıkmıştır (Çetin, 1998: 296). Arapçanın ilk sözlüğü el- Halil tarafından 8. yüzyılın ikinci yarısında yazılmış olan Kitâbu'l- 'ayn'dır. Ancak Cevheri tarafından 10. yüzyılda yazılmış olan Sıhah adlı eserin Arap sözlükçülük tarihinde çok önemli bir yeri vardır. Zira bu eser hem kendinden sonra yazılmış olan Arapça sözlükleri hem de başta Türkler ve Farslar olmak bütün İslam topluluklarının sözlük anlayışlarını derinden etkilemiştir (Aksan, 2007: 70; Öz, 2016: 21).

Arap sözlükçülüğünün etkisiyle şekillenen Türk sözlükçülüğü, Kaşgarl1 Mahmut’un büyük eseri Divan-ı Lûgâti't-Türk'le başlamıştır. Sonrasında, Harezm sahasında yazılmış Mukaddimetü'l-Edeb, Hilyetü'l-İnsân ve Habbetü'l-Lisan, Tibyân-ı Lûgâti't-Türk 'alâ Lisâni'l-Kanklı ve Kıpçak sahasında kaleme alınmış Codex Comanicus, Kitâb-ı Mecmu-ı Tercüman-ı Türkî ve Acemî ve Mugalî, Kitâbü'lİdrâk li-Lisâni'l-Etrâk, Kirâbü'l-Ef'al, Kitâbü't-Tuhfeti'z-Zekiyye fil-Lûgati't-Türkiyye, Kitâbü Bulgatü'l-Müştâk fî Lûgati't-Türk ve'l-Klfçak, Ed-Durretü'l-Mudiyye fi'l-Lûgati't-Türkiyye, EşŞüzurü'z-Zehebiyye ve'l-Kitau'l-Ahmediyye fi'l-Lûgati't-Türkiyye gibi eserlerle büyük gelişme göstermiştir. Çağatay, İran ve Hint sahalarında düzenlenmiş Muhakemetü'l Lûgateyn, Abuşka Lûgati, Bedayiü'l-Lûgat, Senglah, Hulâsa-i Abbasî, Lûgat-ı Çăgatay ve Türkî-i Osmânî, Fazlullah Han Lügati,

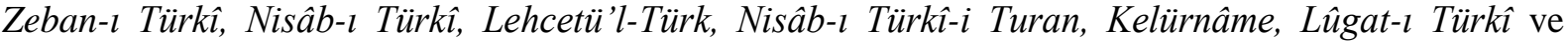
Anadolu sahasında tertip edilmiş Lûgat-ı Ferişteoğlu, Miftahu'l-Edeb, Tuhfetü'l-Şadî, Kitab-ı Lugat-ı Vankulu, Lehçet-ül Lugat gibi onlarca sözlükle de köklü bir Türk sözlükçülük geleneği oluşmuştur. Başlangıçta yabancı bir dilin söz varlığını Türkçeye aktarmak amacıyla yazılan bu eserler zamanla Türkçenin söz varlığını yabancı dillere aktaran veya Türkçe kelimeleri açıklayan eserlere dönüşmüştür. 
Pek çok gayeyle oluşturulan sözlüklerin yazılma amaçlarından biri de yabancı bir dili öğretmektir (İlhan, 2007: 22; Karadüz, 2009: 639). Osmanlıdaki ilk sözlükler de yabancı bir dili öğretmek maksadıyla hazırlanmış iki dilli sözlüklerdir. Bu tür sözlüklerin ilk örneği, Ferişteoğlu tarafından XIV. yüzyılda Arapça - Türkçe düzeninde kaleme alınmış olan Lûgat-ı Ferişteoğhu'dur (Ülkütaşır, 1948: 49). Türkçe temelli yani Türkçe kelimeler madde başı yapılarak oluşturulan sözlükler ise 18. yüzyılın ortalarından itibaren görülmeye başlamıştır (Akalın: 2017: 39; Yavuzarslan, 2009;13). $\mathrm{Bu}$ tarihten önce yazılmış sözlükler daha ziyade Arapça veya Farsça kelimelerin madde başı olarak alınması suretiyle tertip edilmiş eserlerdir.

Aynı kültürel daire içerisinde bulunulan Arapça ve Farsça Osmanlı aydınları tarafından benimsenmiş ve yoğun olarak kullanılmıştır. Bu dillerin bilim, din ve edebiyat dili olarak yaygınlık kazanması Arapça - Türkçe, Farsça - Türkçe gibi iki dilli sözlüklerle Arapça - Farsça - Türkçe, Farsça Arapça - Türkçe gibi çok dilli sözlüklerin oluşmasına zemin hazırlamıştır (Akalın, 2017: 39). Çok kültürlü bir yapıya sahip olan Osmanlı toplumunda, Arapça ve Farsça söz varlığını içeren sözlüklerin yanında, birlikte yaşanan veya kültürel, siyasi ve iktisadi münasebetler kurulan milletlerin dillerini içeren sözlükler de hazırlanmıştır. 17. yüzyıldan itibaren içerisinde Türkçenin yanı sıra, Yunanca, Ermenice, Fransızca, İtalyanca, Afganca, Hintçe, Keşmirce gibi dillerin yer aldığı çok dilli sözlükler de görülmeye başlamıştır. Bu sözlüklerden biri de 17. yüzyılın ikinci yarısında Hintçe - Farsça - Türkçe düzeninde tertip edilmiş olan Terceme-i Lûgat-ı Hindî (THL)'dir.

Türk - Hint münasebetleri oldukça eskiye dayanır. Türklerin Hint yarımadasındaki varlıkları M.Ö. 170'lere kadar uzanır (Kulke ve Rothermund, 2004: 77; Durak, 2008: 138). Hint kitabelerindeki kayıtlara göre Hunlar 5. yüzyılın sonları ile 6. yüzyılın başlarında orta Hindistan ve Keşmir'i içine alan bir imparatorluk kurmuşlardır (Tezcan 2006: 20). Ancak Türklerin burada, tam anlamıyla, siyasi ve kültürel varlık göstermeleri bu bölgede kurulan ilk Müslüman Türk devleti Gazneliler zamanına denk gelmektedir. Gazneliler'den sonra Türkler, 1206'dan 1857'e kadar kurdukları Delhi Türk Sultanlığı, Kurbîler, Balabanlar, Kalaç Sultanlığı, Tuğluklular, Seyyidîler, Lodîler ve Babur Devleti ile Hindistan'da hüküm sürmeye devam etmiştir.

Hint tarih ve kültürünü etkileyen en önemli Türk devleti Babur İmparatorluğu'dur. 1526'dan 1857'ye değin egemenliğini sürdüren bu devlet zamanında pek çok Türkçe eser yazılmıştır (Rasonyı, 1971: 162). Başta Türk sultan ve şehzadeleri olmak üzere pek çok şair Türkçe şiirler yazmış ve divanlar tertip etmiştir. Babür Şah ve Bayram Han'dan başka Pinhanî, Mîrîm Beg, Mirza İbrahim Cânı, Hümâyûn, Kâmrân Mirzâ, Süleyman Şah Mirza, İbrahim Mirza, Hüseyin Argun, Abdürrahim Han, Kelb-i Ali Beg, Hemedanlı Siyanî, Derviş Mislî ve Mîr Yûnus Muhammed Han gibi pek çok şair ve yazar Çağatay Türkçesiyle eserler vücuda getirmişlerdir (Bilkan, 1998: 12-13).

Edebî alandaki bu canlılık kendisini sözlükçülük alanında da göstermiş ve Hindistan'da, bünyesinde Türkçenin söz varlığını da barındıran pek çok sözlük yazılmıştır. Farsça, bu sözlüklerde kendine daima yer bulmuştur. Bu durumun temel sebeplerinden biri çok kültürlü ve çok dilli bir yapıya sahip olan Hint toplumunda Farsçanın oldukça uzun bir süre resmi dil konumunda bulunmasıdır. Bir diğer sebep ise Farsçaya yakın dillerle Farsçanın bazı lehçelerinin halk arasında yoğun olarak kullanılmasıdır. (Turan, 2017: 288). Öyle ki 19. yüzyıla kadar Hindistan'da tertip edilmiş olan 38 Türkçe yazma sözlügün 28'i ya Türkçe-Farsça ya da Farsça-Türkçe şeklinde düzenlenmiştir (Karomat, 2005: 39-41; Öz, 2016: 316-334). Bu sözlüklerin hemen hepsinde kullanılan Türkçe ise, bu bölgede tıpk1 Farsça gibi çok önemli bir konumda bulunan Çağatay Türkçesidir.

Hint coğrafyasında hem Hintçenin hem de Türkçenin söz varlığını içeren Cevâhir-nâme-i Kalem, Garaibü'l-Lûgat, Nisâb-ı Şeş Zebân(Nisâb-ı Şeş Lûgat), Lûgat-ı Türkî ve Fârsî̀ ve Arabî ve Hindî, Lûgat-ı Arabî Fârsî Hindî Türkî ve Agrezî, Nisâb-ı Şeş Lûgat gibi çok dilli sözlükler tertip edilmiştir. Yazmalardaki tarihlere göre, Babur hükümdarı Âlemgir (1658-1707) döneminden itibaren düzenlenen bu sözlüklerde (Karomat, 2005: 39) siyasi, dini, idari ve ticari ihtiyaçları karşılamak 
maksadıyla Türkçe ve Hintçenin yanında Farsça, Arapça, Keşmirce, Urduca ve Peştuca gibi dillere de yer verilmiştir. Baharat yolu sebebiyle bölgede yoğun bir ticari faaliyetin olması bu çok dilli sözlükleri oluşturan temel etkendir.

Osmanlı ve Babur İmparatorlukları arasında siyasi ve diplomatik ilişkilerin tesis edildiği bilinmektedir. Yavuz Sultan Selim ile Ubeydullah Han ve Kanuni Sultan Süleyman ile Abdüllatif Han arasındaki mektuplaşmalar iki ülke arasındaki siyasi ilişkileri canlandırmıştır. Seydi Ali Reis kumandasındaki Osmanlı donamasının Hindistan'a gönderilmesi de ilişkileri kuvvetlendiren bir diğer unsurdur. Devletler arasındaki münasebetler Babur İmparatorluğu'nun yıkılışına kadar devam etmiştir. (Özcan, 1997: 5-30)

Osmanlı ve Babur İmparatorlukları arasındaki siyasi ve diplomatik hareketlilik kültürel alanda pek fazla hissedilmemiştir. Mesafenin çok büyük olması ve her iki coğrafyada Farsçanın yoğun olarak kullanılması gibi sebeplerle Osmanlı aydınları Hintçeye pek ilgi duymamıştır. Bu durum Osmanlı sözlükçülüğünü de etkilemiş, Osmanlı coğrafyasında, bildiğimiz kadarıyla, TLH'den başka Hintçe Türkçe sözlük tertip edilmemiştir.

\section{Terceme-i Lûgat-ı Hindî’nin Yazarı}

$T L H, 17$. yüzyılın önemli âlimlerinden Hezarfen Hüseyin Efendi tarafından kaleme alınmıştır. Doğum tarihi hakkında kesin bilgi sahibi olamadığımız Hüseyin Efendi, İstanköy (Kos) adasında dünyaya gelmiş ve eğitim hayatına burada başlamıştır (Babinger, 2003: 201). Tahsilini İstanbul'da tamamladıktan sonra devlet hizmetine girmiş ve çeşitli memurluklarda görev almıştır (Bursalı, 1343: 243). Sarayda bulunduğu dönemde, IV. Mehmet'in tarih hocalığını yapmış olan Hüseyin Efendi, bir süre de Dîvân-1 Hümâyun tercümanı Ali Ufkî Bey'in yanında vazife görmüştür. (İlgürel, 2004: 544). 1668 'de bir yıl süreyle Sakız Emini olarak görev yapmış olan Hüseyin Efendi, bir müddet sonra memuriyetten ayrılarak tamamıyla ilimle meşgul olmuştur (Şaş, 2014: 11). Ardında tarihten tıbba, sözlükçülükten dini ilimlere çok faklı alanlarla ilgili on altı eser bırakması sebebiyle Hüseyin Efendi'ye "hezarfen" lakabı uygun görülmüştür (Bayrak, 2002: 174). 1678 veya 1691'de vefat ettiği düşünülen Hezarfen Hüseyin Efendi'nin nerede öldüğü ve nereye defnedildiği hakkında bir bilgi bulunmamaktadır (Bursal1, 1343, 244; İlgürel, 2004, 544; Lewis, 1962, 121; Yurdaydın, 1971, 134). Ancak, Hüseyin Efendi'nin $T L H$ 'yi hicri 1 Cemaziyelevvel 1089 'da (21 Haziran 1678) yazmaya başladığı göz önüne alınırsa 1691'de vefat ettiği görüşünün daha kuvvetli olduğu kabul edilebilir.

Daha ziyade tarihçi yönüyle tanınmış olan Hezarfen Hüseyin Efendi aynı zamanda önemli bir dil bilgini ve sözlükçüdür. Arapça ve Farsçanın yanında Yunaca, İbranice ve Latince gibi dillere de hâkim olan Hezarfen, TLH'den başka Tuhfetü'l-Erîbin-Nâfi'a lir-Rûhânî ve'-Tabîb, Lisânü̈l-Etibbâ fî Lûgati'l-Edviye, Fihrisü'l-Ervâm gibi sözlüklerin de yazarıdır.

\section{Terceme-i Lûgat-ı Hindî’nin Adı ve Nüshası}

Bugüne kadar üzerinde herhangi bir inceleme yapılmamış olan Terceme-i Lûgat-1 Hindî’nin bilinen tek nüshası İstanbul Üniversitesi Nadir Eserler Kütüphanesi TY 5796 numarada bulunmaktadır. Yazmanın ikinci satırında, eserin isminin "Terceme-i Lûgat-1 Hindî" şeklinde verilmiş olmasına karşın eserin başında, sonradan yazılmış olduğu anlaşılan, "Kitâb-1 Lûgat-1 Hindî" kaydı bulunmaktadır. O sebeple eser, İstanbul Üniversitesi Nadir Eserler Kütüphanesinde "Kitâb-1 Lûgat-1 Hindî” şeklinde kayitlidir.

Hicri 1 Cemaziyelevvel 1089 'da (21 Haziran 1678) yazılmaya başlanan Terceme-i Lûgat-1 Hindî'nin müellif hattı bugün için meçhuldür. Elimizdeki tek nüsha hicrî 1221'de (1806/1807) istinsah edilmiştir. Eserde herhangi bir kayıt bulunmaması sebebiyle eserin müstensihi ve tamamlanma tarihine dair bir bilgimiz yoktur. 


\section{Terceme-i Lûgat-ı Hindî’nin Sözlük Bilimsel Özellikleri}

\subsection{Sözlüğün Türü}

Sözlükler yazılış amaçları, kullanım yöntemleri, iç unsurları ve sahip oldukları özelliklere göre çok farklı şekillerde tasnif edilebilir (Ahanov, 2008: 187-217; Aksan, 2007: 69-87; Atkins ve Rundell, 2008: 24; İlhan, 2009: 537-538; Kocaman 1998: 111). TLH, Atkins ve Rundell'in (2008: 24-25) ortaya koyduğu ilkelerden hareketle genel amaçlı, standart boyutlu, yazılı, sözcükten anlama gidecek şekilde düzenlenmiş, sözlükte kullanılan dillerin dünya çapındaki öğrenicilerine hitap eden, yetişkin ve kültürlü bir kitleyi hedefleyen, yabancı dilde yazılmış bir metni anlamaya yönelik, çok dilli, tarihi bir sözlük olarak nitelendirilebilir.

\subsection{Sözlüğün Yapısı}

\subsubsection{Fiziki Özellikler}

200 x 125 mm boyutunda kahverengi meşin bir cilt içinde bulunan TLH, 69 sayfadan ibarettir. Nesih hatla, her sayfasında 19-23 satır bulunacak şekilde düzenlenmiștir. Başlıklar ve madde baş1 kelimeler kırmızı, diğer kısımlar ise siyah mürekkeple yazılımıştır. Eserin 2/a, 2/b, 4/a, 4/b, 5/a, 5/b, 6/b ve 9/a sayfalarında istinsah esnasında unutulmuş bazı maddeler derkenarda verilmiştir.

\subsubsection{Genel Yapı}

Tarihî Türk sözlükleri genellikle ön bilgi, sözcük listesi ve son bilgi olmak üzere üç ana bölümden oluşur. TLH'nin ilk iki sayfasında ön bilgi bölümü bulunmaktadır. Geriye kalan 67 sayfalık bölümde ise sözcük listesi vardır. "tamâmü'l-kitâb" ibaresiyle sonlanan eserde son bilgi bölümü bulunmamaktadır.

\subsection{3. Ön Bilgi}

Tarihi Türk sözlüklerinin bu bölümü genellikle besmele ve dua ile başlar. Bölümün devamında yazarın adı, hayatı; sözlüğün adı, telif sebebi, içeriği, amacı, hedef kitlesi, yöntemi; sözlük hazırlanırken faydalanılan kaynak eser ve kişiler hakkında bilgi ile fihrist ve doğru-yanlış cetveli gibi unsurlara yer verilir (Aslan, 2017: 66).

$T L H$ 'nin ön bilgi kısmı besmele ve dua ile başlamaktadır. Devamında yazarın adı ve nereli olduğunun yanı sıra eserin adı, telif sebebi, amacı, hedef kitlesi ile sözlük hazırlanırken faydalanılan kaynak kişi hakkında bilgi verilmiştir:

(...) sebeb-i Terceme-i Lûgat-ı Hindî budur ki bir rûz-ı fîrûz ve zemân-ı meymenetendûzda bu 'abd-i fakîr Hüseyn'ül-med 'üvv be-Hezâr-fenn sâbıka def'a-i sâniyede sadrı refí 'ul-kadr Rûm ilide bezl-nevâl-i 'adl ü dâd iden fâzıl-ı 'adîm'ül-mu' âdil bahr-ı muhît$i$ 'ulûm-ı bilâ-nihâye câmi '-i fezâyil ü ma 'ârif-i bî-gâyet el- 'âlimu'l-'allâme vel-kıdvetü'lfahâmet zübdetü'l-mahâdîmu'l-kirâm'ul-mevlâyu'l-müreddef be-şeyh-i Muhammedü'l'İzzî Efendi hazretlerinü̈ ser-menzil-i füyûzât-ı sübhânı olan sa 'âdet hânelerinde erbâbI fazl u kemâl ve ashâb-ı 'izz ü celâl ki her biri mahall-hân-ı kâfiye-güzâr ve fasîh zebâni sihr-âsâr ile cem 'olub o şem '-i bezm-ârâ-yı fazl u kemâlüy etrâfinda pervâne-veş 'akd$i$ halka-i sohbet oldukda meclis-i dil-güşâlarında erbâb-ı ma ârifden birinde zebân-ı Fârisî ve Hindî ile mülemmâ bu ebyât vardı ki bu mahalde tahrîr olundı (...) bu ebyât-ı manzûr girişme-i 'âtıfetleri oldukda gerçi zebân-ı Fârisî me'lûf oldukları lisân lâkin elfâz$\imath$ Hindî gayr-ı mesmû' olmagın ebyât-ı merkûma hall olunmagla bu bende-i bî-mikdâr ve kemîne-i hâk-sârlarına teveccüh ve hitâb-ı vâcibü't-ta 'azzumları vârid olub lisân-ı Hindîden ilâ-hazâ 'l-ân efrâd-l âfrîdeden bir ferd bir lûgat tercüme itmemişdür sen lûgat$\iota$ Hindîyi Türkîye tercüme eylesẹ bir eser-i cerîde olurdı deyü buyurduklarinda binâen 'aleyh semend-i himmet hizmet-i tercüme-i luggat tarafina sevk olundukda (...) esbâb-ı 
mefhûmı üzere ol eyyâmda Özbek elçisiyle gelmişs Monla Feyzullah nâm kimesneye mukârin olub mezbûr zebân-ı Fârsî ve lisân-ı Hindîye 'ârif bir kâyil vücûd olmagla hicret-

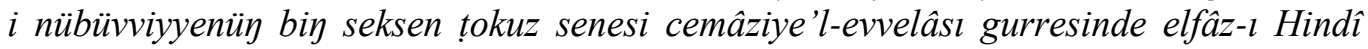
lûgat-ı Fârsî ve lisân-ı Türkî ile tercümeye şürû' olındı ve billâhi't-tevfîk (Hezarfenn, 1678: 1-2)."

Buradaki açıklamalardan anlıyoruz ki Osmanlı coğrafyasında kaleme alınmış ilk Hintçe-FarsçaTürkçe sözlük olma özelliğini taşıyan TLH, Özbek elçisiyle İstanbul'a gelmiş olan Molla Feyzullah adlı kişinin yardımıyla, edebiyatla ilgilenen entelektüel bir kitlenin ihtiyaçlarını karşılamak için kaleme alınmıştır.

Diğer taraftan bu bölümde, eserin hangi yöntemle hazırlandığı, eseri kullananların nelere dikkat etmesi gerektiği ve madde başlarının seçiminde hangi kıstasların göz önünde bulundurulduğu gibi konulara değinilmemiştir. Bu tür çok dilli sözlülerin o dönemde yoğun olarak kullanılması ve kullanıcıların bu bilgilere sahip olduğu fikri, yazarı böyle bir yola sevk etmiş olabilir.

\subsection{4. İç Yapı}

İç yapı, sözlüğün ana gövdesini oluşturan kelime listesinden oluşmaktadır. TLH'nin iç yapısı, el-Bermekî ekolü denilen ve Arap sözlükçülerin 11. yüzyıldan itibaren kullanmaya başladıkları alfabetik sisteme göre düzenlenmiştir. Eserdeki madde başları, Arap alfabesindeki sıra esas alınarak hece sisteminde dizilmiştir. Yani madde başları, kelimenin ilk harfinin harekesine göre önce üstün sonra kesre ve son olarak da ötre olmak üzere üç bölümde sıralanmıştır. Eserde toplam 623 Hintçe madde baş1 kelime ve kelime öbeğinin Farsça ve Türkçe karşılıkları verilmiştir. Toplam 24 bap ve 36 fasıldan oluşan

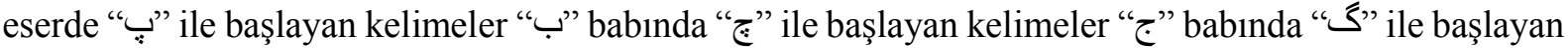
kelimeler ise " " " babında verilmiştir. Eserdeki bap ve fasılların düzeni şu şekildedir:

\begin{tabular}{|c|c|c|c|c|c|}
\hline bap & sayfa & fasıl & sayfa & fasıl & sayfa \\
\hline bâbu'l-elîfü'l-meftûha & 3 & faslu'l-elifü'l-meksûre & 7 & faslu'l-elifü'l- mazmûme & 7 \\
\hline bâlu'l-bâi'l-meftûha & 9 & faslu'l-bâi'l-meksûre & 16 & bâbu'l-bâi'l-mazmûme & 18 \\
\hline bâbu't-tâi'l-meftûha & 21 & faslu't-tâi'l-meksûre & 22 & faslu't-tâi'l-mazmûme & 23 \\
\hline bâbu'l-cîmü'l-meftûha & 24 & faslu'l-cîmü'l-meksûre & 27 & faslu'l-cîmü'l-mazmûme & 29 \\
\hline bâbu'l-hâi'l-meftûha & 31 & faslu'l-hâi'l-meksûre & 31 & faslu'l-hâi'l- mazmûme & 31 \\
\hline bâbu'l-hâi'l-meftûha & 32 & & & faslu'l-hâi'l-mazmûme & 33 \\
\hline bâbu'd-dâi'l-meftûha & 33 & faslu'l-dâli'l-meksûre & 35 & faslu'l-dâli'l-mazmûme & 36 \\
\hline bâbu'z-zâl & 37 & & & & \\
\hline bâbu'r-râi'l-meftûha & 37 & faslu'r-râi'l-meksûre & 38 & faslu'r-râi'l-mazmûme & 39 \\
\hline bâbu'z-zâi'l-meftûha & 39 & faslu'z-zâi'l-meksûre & 40 & faslu'z-zâi'l-mazmûme & 40 \\
\hline bâbu's-sînü'l-meftûha & 40 & faslu's-sînü'l-meksûre & 41 & faslu's-sînü'l-mazmûme & 42 \\
\hline bâbu'ş-şînü'l-meftûha & 44 & faslu'ş-şînü'l-meksûre & 45 & faslu'ş-şînü'l-mazmûme & 45 \\
\hline bâbu's-sâdu'l-meftûhâ & 45 & faslu's-sâdu'l-meksûre & 46 & faslu's-sâdu'l-mazmûme & 47 \\
\hline bâbu'l-'ayn & 47 & & & & \\
\hline bâbu'l-ġaynü'l-meftûhâ & 47 & & & faslu'l-'gaynü'l-mazmûme & 47 \\
\hline bâbu'l-fầ'il-meftûha & 48 & faslu'l-fâ'il-meksûre & 49 & & \\
\hline bâbu'l-kâfu'l-meftûha & 49 & faslu'l-kâf'ul-meksûre & 49 & faslu'l-kâfu'l-mazmûme & 49 \\
\hline bâbu'l-kâf'ül-meftûha & 50 & faslu'l-kâf'ül-meksûre & 54 & faslu'l-kâf'ül-mazmûme & 56 \\
\hline bâbu'l-lâmu'l-meftûha & 58 & faslu'l-lâmu'l-meksûre & 60 & faslu'l-lâmu'l-mazmûme & 60 \\
\hline bâbu'l-mîmu'l-meftûha & 61 & faslu'l-mîmu'l-meksûre & 62 & faslu'l-mîmu'l-mazmûme & 63 \\
\hline bâbu'n-nûnu'l-meftûha & 64 & faslu'n-nûnu'l-meksûre & 66 & faslu'n-nûnu'l-mazmûme & 66 \\
\hline bâbu'l-vâv & 67 & & & & \\
\hline bâbu'l-hâi'l-meftûha & 67 & faslu'l- hâi'l-meksûre & 68 & faslu'l-hâi'l-mazmûme & 69 \\
\hline bâbu'l-yâ'il-meftûha & 69 & & & & \\
\hline
\end{tabular}


Eserdeki maddeler, pek çok el yazması sözlükte olduğu gibi, satır içerisinde birbiri ardınca verilmiştir. Bu durum kelime bulmayı zorlaştırmıştır. Ancak eserin bap ve fasıllara ayrılmasıyla bap, fasıl ve madde başı kelimelerin kırmızı mürekkeple yazılmış olması bu zorluğu, bir nebze de olsa ortadan kaldırmıştır.

\subsubsection{Maddenin Yapısı}

Maddenin başında, Arap alfabesine göre sıralanmış olan Hintçe madde başı söz veya söz öbeği bulunmaktadır. Madde başından hemen sonra Farsça ve Türkçe karşılılara yer verilmiştir. Maddenin sonunda ise dil bilgisel bilgi, kullanım etiketi ve örnek gibi unsurlar yer almıştır. Ancak bu unsurlar her maddede standart olarak bulunmamaktadır. Çoğu maddede bu unsurlardan sadece birine yer verilirken bazı maddelerde birkaçına yer verildiği görülmüştür.

\subsubsection{Madde Başı}

Kapsamı itibarıyla genel amaçlı bir sözlük olan $T L H$ 'nin madde başlarının seçiminde nasıl bir ölçütün kullanıldığını bilemiyoruz. Ancak şunu söyleyebiliriz ki eserdeki 623 madde başının tamamına yakını günlük hayatta çokça kullanılan söz veya söz öbeklerinden oluşmuştur. Madde başları, kullanım kolaylığı sağlamak amacıyla, kırmızı mürekkeple yazılmıştır.

\subsubsection{Sesletim Bilgisi}

Eserde sadece madde başı kelimelerin sesletim bilgisine yer verilmiştir. Madde başlarının tamamında bulunan harekeler sayesinde kelime veya kelime öbeklerinin nasıl telaffuz edilmesi gerektiği belirtilmiştir:

\section{حَأَّarvâh] Fârisîde revân ve Türkîde cân ma 'nâsina. (2/11)}

Eserde Farsça ve Türkçe kelimelerin sesletim bilgilerine yer verilmediğini görüyoruz. Ancak bu durumun birkaç istisnası vardır:

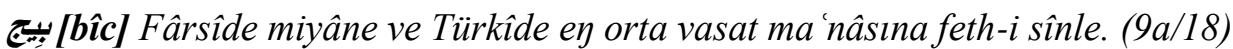

\subsubsection{Tanım Bilgisi}

Eserdeki maddelerin tanımında tam bir birlikteliğin olduğu söylenemez. Hintçe madde başı kelime veya kelime öbekleri, çoğunlukla, önce Farsça sonra Türkçe karşılıkları verilerek tanımlanmıştır. Ancak bu tanım bilgisi her maddede aynı şekilde değildir. Eserde tanım bilgisi için 14 farklı yöntem kullanılmıştır:

4.2.5.3.1. Madde başı kelimenin ardından önce Farsça sonra Türkçe karşılık verilmiş ve madde "dimekdür" sözcüğüyle tamamlanmıştır:

هَأَkâra] Fârsîde şûr ve Türkîde tuzlu dimekdür. (25b/20)

4.2.5.3.2. Madde başı kelimenin ardından önce Farsça sonra Türkçe karşılık verilmiş ve madde “dimek olur" sözcük öbeğiyle tamamlanmıştır:

[نَامى [nâmî] Fârsîde nâmzed ve Türkîde nişanlu dimek olur. (33a/13)

4.2.5.3.3. Madde başı kelimenin ardından önce Farsça sonra Türkçe karşılık verilmiş ve madde "gibi" sözcüğüyle tamamlanmıştır:

اسُعانُ [âsumân] Fârisîde dahı âsumân dirler Türkîde gök semâ gibi. (2b/10)

4.2.5.3.4. Madde başı kelimenin ardından önce Farsça sonra Türkçe karşılık verilmiş ve madde "derler" sözcügüüle tamamlanmıştır:

[alnah] Fârisîde aşiyâne ve Türkîde yuva derler. (3a/3) 
4.2.5.3.5. Madde başı kelimenin ardından önce Farsça sonra Türkçe karşılık verilmiş ve madde "manâsına" sözcügüule tamamlanmıştır:

[كرَّر [karmar] Fârsîde tund ve Türkîde sırt ma 'nâsına. (26b/14)

4.2.5.3.6. Madde başı kelimenin ardından önce Farsça sonra Türkçe karşılık verilmiş ve madde "ma'nâsına gelür" sözcük öbeğiyle tamamlanmıştır:

آلَّilal-pilâ] Fârisîde nâ-pervâ ve Türkîde serâsime ma nâsına gelür. (3a/16)

4.2.5.3.7. Madde başı kelimenin ardından önce Farsça sonra Türkçe karşılık verilmiş ve madde "ibaretdür" sözcüğüyle tamamlanmıştır:

[baht-âvar] Fârsîde sâl-hidâh ve Türkîde sâhib-i tâli 'den 'ibâretdür. (6a/12)

4.2.5.3.8. Madde başının ardından önce Farsça sonra Türkçe karşılık verilmiş ve herhangi bir kelime kullanılmaksızın sonraki maddeye geçilmiştir:

أبنى كوُلدى [abnî gōdî] Fârisîde der-âgûşv ve Türkîde koçmak. (2a/5)

4.2.5.3.9. Madde başı kelimenin ardından önce Farsça sonra Türkçe karş1lık verilmiş ve Türkçe karşıl1k açıklanmıştır:

[âg-cellâu] Fârisîde âteş-efrûz ve Türkîde tutruk ki odı anuyla yakarlar. (2b/13)

[آدهيز [adhîr] Fârisîde dî-mî ve Türkîde kırçll kişi ya nî sakalınuy birezi ag ve birezi kara ola. $(2 b / 6)$

4.2.5.3.10. Madde başı kelimenin ardından önce Farsça sonra Türkçe karşıllk verilmiş, Türkçe karşılıktan sonra çoğu zaman Türkçe olmayan bir açıklayıcı ibare eklenmiş ve madde "manâsına" sözcüğüyle tamamlanmıştır:

[وَّōra] Fâsîde esb ve Türkîde at feres ma 'nâsina. (28b/2)

[kufa kardan] Fârsîde hafa kerden ve Türkîde boğmak haba kerden ma 'nâsına (29a/3)

4.2.5.3.11. Madde başı kelimenin ardından "ya "nî” sözcüğü getirilip Farsça karşlık verilmiş, ardından "be-manâ" sözcüğü eklenip Türkçe karşılıkla madde tamamlanmıştır:

[partâ-hiya] ya nî mîgerdem be-ma 'nâ dönmek. (7a/10)

4.2.5.3.12. Madde başı kelimenin Farsça ve Türkçe karşı1ıklarının aynı olduğu durumlarda, madde başından sonra "Fârsîde ve Türkîde dahı" ifadesi kullanılmış ve madde genellikle her iki dilde de kullanılan bir söz veya söz öbeğiyle tamamlanmıştır:

كצllâk] Fârsîde ve Türkîde dahı lâden dirler. (30a/17) verilmiş:

4.2.5.3.13. Bazı maddelerde, Farsça ve Türkçe karş1l1klardan sonra Arapça karşı1lığa da yer

[makray] Fârsîde delmek ve Türkîde bö didikleri agulı böcek örümcek envâ 'indan bir nev'dür 'Arabca ruteylâ dirler. (31a/13)

4.2.5.3.14. Hintçe-Farsça-Türkçe şeklindeki sıralama sadece bir kez Hintçe-Türkçe-Farsça şeklinde kurgulanmıştır:

تينين][tîn] ve Türkîde üç ki Fârsîde se dirler sülüs ma 'nâsina. (11b/19) 


\subsubsection{Dil Bilgisel Bilgi}

$T L H$ 'nin pek çok maddesinde dil bilgisel bilgiye yer verilmiştir. Genellikle kelimelerin türleri ve fiillerin çatılarıyla ilgili olan bu bilgi her maddede düzenli bir şeklide verilmemiştir. Yazar sadece gerekli gördüğü maddelerde, genellikle tek dil bilgisel bilgiye yer vermiştir:

كوّي [givvî] Fârsîde rugân ve Türkîde yag derler ism-i 'âmdur. (28a/9)

جَامَه [câme] Fârsîde dahı câme ve ve Türkîde ton derler ism-i cinsdür. (12b/15)

[kōdna] Fârsîde fagand ve Türkîde sıçramak ma 'nâsına ism-i masdardur. (29b/4)

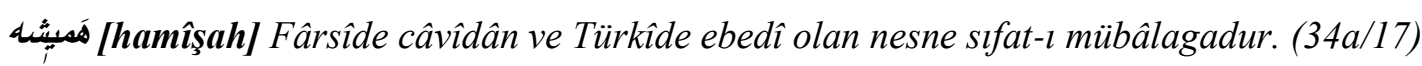

@) [ih] Fârsîde în ve Türkîde bu dimekdür esmâ'-i işâretdendür. (4a/11)

[ُ [tum] Fârsîde îşân ve Türkîde anlar zamîr-i cem 'dür hüm ve hünne ma 'nâsına. (12a/3)

[ذَنَانَ [daranâ] Fârsîde hirâsân ve Türkîde korkak sîgâ-i mübâlagadur. (17b/19)

[cự̂â-kerna] Fârsîde çû ve Türkîde harf-i ta lîldür çünki ma 'nâsına. (15b/2)

Eserde kelimelerin doğruluk yanlışlık bilgisine de yer verilmiştir. Bazı maddelerde kelime veya kelime öbeğinin önce doğru, sonra da yanlış kullanımı gösterilmiştir:

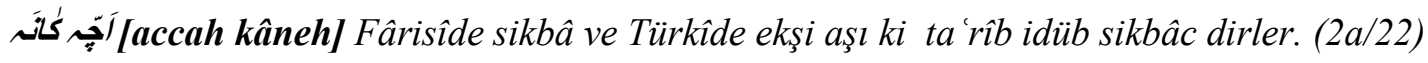

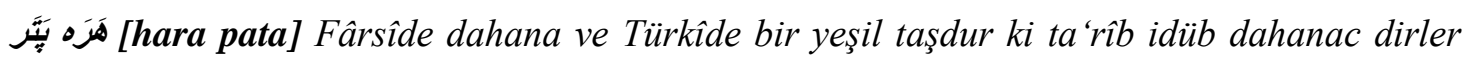
$(34 b / 9)$

\subsubsection{Köken Bilgisi:}

Çok dilli bir sözlük olması sebebiyle $T L H$ ' de köken bilgisine de yer verilmiştir. Ancak bu bilgi, kelimenin kökeninden ziyade hangi dilde kullanıldığını göstermektedir. Zira eserde Hintçe, Farsça ve Türkçe olarak gösterilen pek çok kelime köken itibarıyla başka dillere aittir:

إنعاْ [in 'âm] Fârsîde bahşîlden ve Türkîde bagışlamak hibe ma 'nâsına. (4a/6)

بَه [bah-hud] Fârsîde gulüvvv ve Türkîde mübâlaga dimek olur. (8b/2)

\subsubsection{Kullanım Etiketi:}

$T L H$ 'nin bazı maddelerinde, kelimenin hangi alanda veya hangi durumda kullanıldığına dair bilgiye de yer verilmiştir:

- [âh] Fârsîde vâh ve Türkîde râstllk ve dürüstlük her nesneye sifat olur. (3a/19)

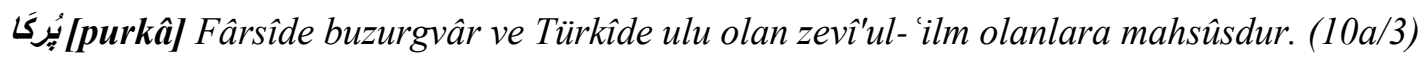

[مَآنتتى [mâyantî] Fârsîde peymâne ve Türkîde ölçü ekser budur ki şarâb ölçiçekde isti 'mâl olunur. $(31 a / 3)$

\subsubsection{6. Örnek}

$T L H$ 'de yer yer madde başı kelime veya kelime öbekleriyle bunların Farsça ve Türkçe karşılıklarının örnek kullanımlarına yer verilmiştir. Bu örneklerin tamamı kelime öbeği şeklindedir:

[ُبرَه بُو [purabû] Fârsîde hudâvend ve Türkîde issi sâhib ma 'nâsına hudâvend-i mâl gibi

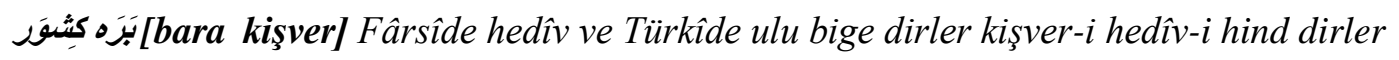
$(6 b / 2)$ 
[haulî] Fârsîde asta ve Türkîde çekirdek meselâ hurmanuך ve keçi boynuzı çekirdegi (34a/14)

Eserde, bazı madde başlarının tekrar edilmesi ve bazı maddelerin yarım bırakılması gibi aksaklıklar bulunmaktadır. Bu aksaklıkların, büyük oranda, müstensih kaynaklı olduğu kanaatindeyiz.

\section{Sonuc}

Çok dilli sözlüklerin yazılma amaçlarından biri de farklı dillere sahip toplumlar arasında siyasi, ticari ve kültürel münasebetlerin sağlanmasını kolaylaştırmaktır. TLH de Hintçe bilmeyen Osmanlı aydınının bu dille yazılmış edebi ve bilimsel eserleri okuyabilmesi maksadıyla tertip edilmiştir. 17. yüzyılın ikinci yarısında yazılmış olan eser, Osmanlı toplumunda Arapça ve Farsçanın yanında Hintçe gibi dillere de ilgi duyulduğunu ve bu dönemde Hint - Türk münasebetlerinin arttığını göstermektedir. Hezarfen Hüseyin Efendi'nin eseri düzenlerken, Özbek elçisiyle İstanbul'a gelmiş olan Molla Feyzullah adlı bir kişiden yardım alması hem kendisinin bu dile vakıf olmadığının hem de İstanbul' da bu dili bilen kişilerin bulunmadığının delilidir. Eser, Osmanlı Dönemi'nde kaleme alınmış tek Hintçe - Farsça Türkçe sözlük olması yönüyle Türkçe - Hintçe/Urduca ilişkilerinin tarihi seyrinin aydınlatılmasına katkı sağlayacaktır.

Yaptığımız inceleme neticesinde eserin; sesletim bilgisi, tanım bilgisi, köken bilgisi, örnek bilgisi, dil bilgisel bilgi ve kullanım etiketi gibi unsurları bünyesinde barındırdığını gördük. Toplam 69 sayfa ve 623 maddeden ibaret olan TLH hem zengin bir kelime dağarcığına sahip olması hem de çok dilli tarihi Türk sözlüklerinin karakteristik özelliklerini yansıtması yönüyle Türk sözlük bilimi için oldukça önemli bir eserdir.

\section{KAYNAKÇA}

Ahanov, K. (2008). Dilbilimin Esasları. (çev. Murat Ceritoğlu). Ankara: TDK.

Akalın, Ş. H. (2010). Sözlüğün Tarihi. Türk Dili: Dil ve Edebiyat Dergisi. XCVIII (699). 268-279.

Akalın, H. Ş. (2017). Geçmişten Günümüze Türk Sözlükçülüğü. Ankara: Elginkan.

Aksan, D. (2007). Her Yönüyle Dil Ana Çizgileriyle Dilbilim. Ankara: TDK.

Aslan, E. (2017). Sözlükbilimsel İnceleme Yöntemi: Eser-i Şevket Örneği. Turkish Studies International Periodical For the Languages, Literature and History of Turkish or Turkic. Volume 12/30 s. 35-70.

Atkins, S. ve Rundell, M. (2008). The Oxford Guide to Practical Lexicography. New York: Oxford.

Babinger, F. (1992). Osmanlı Tarih Yazarları ve Eserleri (çev. Coşkun Üçok). Ankara: Kültür Bakanlığı Yay.

Bayrak, O. (2002). Osmanlı Tarih Yazarları. İstanbul: Milenyum.

Bilkan, A. F. (1998). Hindistan'da Gelişen Türk Edebiyatı. Ankara: Kültür Bakanlığı Yay.

Bursalı Mehmet Tahir. (1343). Osmanlı Müellifleri. İstanbul: İstanbul Matbaası.

Çetin, N.M. (1998). Arap (Yazı). İslam Ansiklopedisi. C. 3 İstanbul: TDV. 276-309.

Dilaçar, A. (1968). Dil, Diller ve Dilcilik. Ankara: TTK.

Durak, N. (2008). Hindistan'da Saka, Kuşan ve Akhunlar. Tarihte Türk-Hint Illişkileri Sempozyumu Bildirileri 25-28 Haziran 2007. Ankara: TTK Yay. 139-144.

Eminoğlu, E. (2010). Türk Dilinin Sözlükleri ve Sözlükçülük Kaynakçası. Sivas: Asitan. 
Hezârfen Hüseyin Efendi. Kitâb-ı Lügat-ı Hindî. İ.Ü. Nadir Eserler Kütüphanesi. No: TY 5796.

İlgürel M. (1998). Hüseyin Efendi, Hezarfen. İslam Ansiklopedisi. C. 20 İstanbul: TDV. 544-546.

İlhan, N. (2007). Geçmişten Günümüze Türk Sözlükçülük Geleneği ve Türk Dili Sözlükleri. Elazığ: Manas.

İlhan, N. (2009). Sözlük Hazırlama İlkeleri, Çeşitleri ve Özellikleri. Turkish Studies International Periodical For the Languages, Literature and History of Turkish or Turkic. Volume 4/4 Summer s. 534-554.

Kocaman, A. (1998). Dilbilim, Sözlük ve Sözlükçülük. Kebikeç. 6, 111-113.

Karadüz, A. (2009). Sözlük, Sözcük Anlamı ve Öğrenme. Turkish Studies International Periodical For the Languages, Literature and History of Turkish or Turkic. Volume 4/4 Summer s. 636-649.

Karomat, D. (2005). Hindistan'da Türkçe Sözlük Çalışmaları (çev. Ali Çavuşoğlu). Bilimname, 1, 137141.

Kramer, S.N. (1995). Tarih Sümer'de Başlar (çev. M.İlmiyye Çı̆̆). Ankara: TTK Yay.

Kulke, H. ve Rothermund, D. (2004). A History of İndia. New York: Routledge.

Lewis, B. (1962). The Use by Muslim Historians of Non-muslim Sources, Historians of Midle East. London: Oxford University Press, 180-191.

Öz, Y. (2016). Tarih Boyunca Farsça-Türkçe Sözlükler. Ankara: TDK.

Özcan, A. (1997). Pan-İslamizm (Osmanlı Devleti, Hindistan Müslümanlarl ve İngiltere, 1877-1924). Ankara: İSAM.

Rasony1, L. (1971). Tarihte Türklük. Ankara: TKAE.

Şaş, A.K. (2014). Tuhfetü'l-Erîbin-Nâfi'a lir-Rûhânî ve'-Tabîb (Sentaks İncelemesi-Metin-Sözlük) (Yayımlanmamış Doktora Tezi). Kayseri, Erciyes Üniversitesi SBE.

Tezcan, M. (2006). Kuşanlar, Akhunlar ve Eftalitler. Tarihte Türk-Hint İlişkileri Sempozyumu Bildirileri. 31 Ekim-1 Kasım 2002. Ankara: TTK. 9-56.

Turan, F. (2017). Hindistan'da Yazılmış Çağatayca Sözlüklerde At ve Atçılığa Dair Kelimeler. Prof. Dr. Nuri Yüce Armağant. Ankara: Güncel.

Ülkütaşır M. Ş. (1948). XI. Yüzyıldan Günümüze Kadar Yazılmış Başlıca Sözlüklerimiz. Türk Dili Belleten. Seri III, S. 12-13.

Yavuzarslan, P. (2009). Osmanlı Dönemi Türk Sözlükçülüğü. Ankara: Tiydem.

Yıldız, N. (1998). Eskiçağın Başvuru Eserleri ve Eskiçağ Sözlükçülüğü ve Sözlükleri. Kebikeç. 6, 189210.

Yurdaydın, H. G. (1992). Düşünce ve Bilim Tarihi. Türkiye Tarihi. İstanbul: Cem. 249-317. 